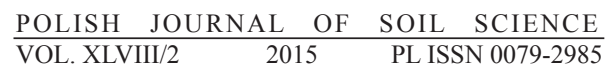

DOI: $10.17951 / \mathrm{pjss} / 2015.48 .2 .189$

Soil Chemistry

\title{
AGNIESZKA ŚLIWIŃSKA*, MICHAŁ DRAB** \\ CHANGES IN THE CONTENT OF HUMIC SUBSTANCES, REACTION AND SORPTION PROPERTIES OCCURRING IN RECLAIMED LAND IN POST-MINING AREAS
}

Abstract. The paper presents selected results of analyses of the properties of post-mining land of the former lignite mine „Przyjaźn Narodów” in the region of Łęknica in the Lubusz Voivodeship. The land formed in that area had very unfavourable properties: its granulometric composition (light clay sand) was susceptible to water erosion, the reaction of the formations was highly acid, the contents of total organic carbon and total nitrogen were varied and highest on the surface level of the profiles. The $\mathrm{C}_{\mathrm{kh}}: \mathrm{C}_{\mathrm{kf}}$ ratios increased as the sampling depth increased.

The development of opencast mining in the region of Łęknica (the Lubusz Voivodeship) has resulted in geomorphological changes. The post-mining land of the post-mining areas of the former lignite mine „Przyjaźń Narodów”, which started operating at the beginning of the 1970s, was subjected to reclamation processes. Reclamation in that area consisted of the following actions [7]: (a) land levelling with bulldozers; (b) soil deacidification with magnesium lime in the Zink Mill „Miasteczko Śląskie” in a dose of $50 \mathrm{Mg} \mathrm{ha}^{-1}$; (c) mineral fertilisation: phosphorus powder in a dose of $5 \mathrm{Mg} \mathrm{ha}^{-1}$, nitro-chalk in a dose of $200 \mathrm{~kg} \mathrm{ha}^{-1}$, ammonium phosphate in a dose of 200 $\mathrm{kg} \mathrm{ha}^{-1}$ and potash salt in a dose of $400 \mathrm{~kg} \mathrm{ha}^{-1}$; and (d) forestation of the area with Scots pines.

Accumulation of organic matter is very important for restoring fertility in post-mining soils and improving their physical, chemical and biological properties [4]. Organic matter in soils undergoes complicated processes which often depend on oxygen-environmental conditions, and produce as a result a number of mineralization products. During the process of humification, humic substances are produced, various fractions of which differ in terms of their immunity to decomposition, time of existence in the environment, and at the same time they determine soil

*A. Śliwińska MSc; Institute of Environmental Engineering, University of Zielona Góra, ul. prof. Z. Szafrana 15, 65-516 Zielona Góra, Poland.

**Asst. Prof. M. Drab, DSc.; Eng.; Institute of Environmental Engineering, Department of Soil Reclamation and Recultivation, University of Zielona Góra, ul. prof. Z. Szafrana 15, 65-516 Zielona Góra, Poland. 
properties [6]. Those processes occur with the participation of microorganisms. Microorganisms in soils are both decomposers participating in the decomposition of organic matter produced by autotrophic organisms and organisms responsible for soil formation processes [1].

\section{MATERIALS AND METHODS}

In 1986 a field experiment was performed in the area under research, near the village of Nowe Czaple, the Administrative Commune of Łęknica. In that area there were plantations of 6-year-old Scots pines ( Pinus sylvestris L.). Plots measuring the dimensions of $35 \times 8 \mathrm{~m}$ were set up in them and different variants of mineral fertilisation were applied according to the scheme:

\section{TABLE 1. MINERAL FERTALIZATION VARIANTS IN THE EXPERIMENT}

\begin{tabular}{|c|c|}
\hline Plot & Mineral fertilization variants \\
\hline 1 & Control - without fertilization \\
\hline 2 & Lime $8 \mathrm{Mg} \mathrm{ha}^{-1}$ \\
\hline 3 & $\mathrm{~N}-100, \mathrm{P}-70 \mathrm{~kg} \mathrm{ha}^{-1}$ \\
\hline 4 & $\mathrm{~N}-100, \mathrm{~K}-160 \mathrm{~kg} \mathrm{ha}^{-1}$ \\
\hline 5 & Lime $8 \mathrm{Mg} \mathrm{ha}{ }^{-1}, \mathrm{~N}-100, \mathrm{P}-70 \mathrm{~kg} \mathrm{ha}^{-1}$ \\
\hline 6 & Lime $8 \mathrm{Mg} \mathrm{ha}^{-1}, \mathrm{~N}-100, \mathrm{~K}-160 \mathrm{~kg} \mathrm{ha}^{-1}$ \\
\hline
\end{tabular}

Mineral fertilisers were used in spring in the years 1987, 1988 and 1989 as follows:

$-\mathrm{N}$ - ammonium nitrate,

$-\mathrm{P}_{2} \mathrm{O}_{5}-$ powdered single superphosphate

$-\mathrm{K}_{2} \mathrm{O}$ - potash salt $50 \%$.

In the autumn of 2010 the upper layer of soil was removed and soil samples were taken for the purpose of laboratory tests. While taking the samples, attention was paid to take them from different depths. The following parameters were found in the profiles: a surface layer of forest litter $-\mathrm{O}$ to the depth of about $0-3 \mathrm{~cm}$, a humus surface layer $-\mathrm{A}$ at the depth of about $3-8 \mathrm{~cm}$ and the bedrock level $-\mathrm{C}$ deeper than $8 \mathrm{~cm}$ without noticeable variation.

The samples of soil material were analysed by means of the methods described by Mock et al. [8]:

$-\mathrm{pH} w \mathrm{H}_{2} \mathrm{O}$ and $1 \mathrm{M} \mathrm{KCl}$ potentiometrically

- hydrolytic acidity - (Hh) and the sum of total exchangeable bases (TEB) by means of the Kappen method

- sorption capacity (CEC) and base saturation (BS)

- total nitrogen $\left(\mathrm{N}_{t}\right)$ by means of the Kjeldahl method

- total organic carbon (TOC) by means of the Tiurin method

Next the samples were subjected to extraction by means of the Schnitzer method [2], applying distilled water and sodium hydroxide without preliminary decalcination. The content of total organic carbon and the content of extracted 
carbon, i.e. humic acid carbon $\left(\mathrm{C}_{\mathrm{kh})}\right.$ and fulvic acid carbon $\left(\mathrm{C}_{\mathrm{kf}}\right)$ were determined by means of the TOC $\mathrm{V}_{\mathrm{CSH} / \mathrm{CSN}}$ analyser made by Shimadzu Company, along with the thermic method (PN-EN 1484 September 1999).

All analyses were repeated three times. The results were subjected to the statistical analysis by means of the Statistica 10a software.

\section{RESULTS AND DISCUSSION}

The dumping grounds of the former lignite mine in Łęknica mainly consist of phytotoxic acid Miocene sands with a different content of lignite chips. Apart from excessive acidity $\mathrm{pH}$ (in $1 \mathrm{M} \mathrm{KCl}$ often above 3.5), an unfavourable feature of those formations arises from negative physical properties (excessive firmness and the tendency to cementation). Those are soils with a composite structure, unfavourable water and air characteristics, extremely poor in mineral components and with low biological activity $[8,9]$. Their susceptibility to water erosion is a considerable obstacle to reclamation of those formations [4].

TABLE 2. SORPTION CHARACTERISTICS OF POST-MINING FORMATIONS

\begin{tabular}{|c|c|c|c|c|c|}
\hline \multirow{2}{*}{ Plot } & \multirow{2}{*}{$\begin{array}{l}\text { Depth } \\
\text { (cm) }\end{array}$} & $\mathrm{Hh}$ & TEB & CEC & \multirow{2}{*}{$\frac{\mathrm{BS}}{(\%)}$} \\
\hline & & \multicolumn{3}{|c|}{$\left(\operatorname{cmol}^{(+)} \mathrm{kg}^{-1}\right)$} & \\
\hline \multirow{4}{*}{1} & $0-3$ & 24.0 & 7.6 & 31.7 & 23.9 \\
\hline & $3-8$ & 12.0 & 5.1 & 17.1 & 29.8 \\
\hline & $8-30$ & 12.6 & 2.9 & 15.5 & 18.7 \\
\hline & $30-60$ & 14.2 & 2.1 & 16.3 & 12.9 \\
\hline \multirow{4}{*}{2} & $0-3$ & 18.8 & 14.0 & 32.8 & 42.7 \\
\hline & $1.5-12$ & 14.0 & 6.6 & 20.6 & 32.0 \\
\hline & $12-30$ & 15.6 & 2.1 & 17.7 & 11.9 \\
\hline & $30-60$ & 10.8 & 1.9 & 12.7 & 14.0 \\
\hline \multirow{4}{*}{3} & $0-2.5$ & 24.0 & 10.8 & 34.8 & 31.0 \\
\hline & $2.5-9$ & 8.0 & 2.1 & 10.1 & 20.8 \\
\hline & $9-30$ & 7.2 & 2.4 & 9.6 & 25.0 \\
\hline & $30-60$ & 10.0 & 2.6 & 12.6 & 20.6 \\
\hline \multirow{5}{*}{4} & $0-3$ & 26.6 & 10.6 & 37.2 & 28.5 \\
\hline & $3-7$ & 11.2 & 3.0 & 14.2 & 21.1 \\
\hline & $7-22$ & 12.8 & 3.0 & 15.8 & 19.0 \\
\hline & $22-42$ & 14.2 & 3.5 & 17.7 & 19.8 \\
\hline & $42-60$ & 10.4 & 1.9 & 12.3 & 15.4 \\
\hline \multirow{5}{*}{5} & $0-3$ & 9.6 & 3.4 & 13.0 & 26.1 \\
\hline & $3-7$ & 9.6 & 4.8 & 14.4 & 33.3 \\
\hline & $7-23$ & 12.0 & 3.4 & 15.4 & 22.1 \\
\hline & $23-32$ & 9.6 & 1.2 & 10.8 & 11.1 \\
\hline & $32-60$ & 10.2 & 1.9 & 12.1 & 15.7 \\
\hline \multirow{4}{*}{6} & $0-3$ & 14.2 & 12.0 & 26.2 & 45.8 \\
\hline & $3.0-10$ & 8.8 & 3.5 & 12.3 & 28.4 \\
\hline & $10-32$ & 12.0 & 1.0 & 13.0 & 7.7 \\
\hline & $32-60$ & 12.0 & 1.7 & 13.7 & 12.4 \\
\hline
\end{tabular}


The sorption characteristics of the post-mining formations under research were strongly varied (Table 2). In samples taken from profiles 1,2 and 3 they were considerably higher than in soil samples from plots 5 and 6 . The Hh values found on forest litter levels highly exceeded the values in samples from deeper levels. The reason for this was probably the acidifying influence of decomposing forest litter - pine needles.

The sorption capacity CEC of samples from forest litter levels - $\mathrm{O}$ and from the surface level - A clearly exceeded the values found at deeper levels of all profiles, where they were very low. The reason for this was probably the strong acidification of post-mining formations.

The saturation of the sorption complex with bases BS was very low and fluctuated between 7.7 and $42.7 \%$. The authors Krzaklewski et al. [10] obtained similar results while researching post-mining formations of the former mine "Przyjaźń Narodów" in other locations.

The reaction of the post-mining formations under research was acid, and their $\mathrm{pH}$ values measured in terms of $\mathrm{H}_{2} \mathrm{O}$ were within the range of 6.3 to 3.2, and $\mathrm{pH}$ in terms of $\mathrm{KCl}$ - from 5.4 to 3.0 (Table 3). Soil $\mathrm{pH}$ values had the tendency to decrease as the sampling depth increased.

The formations under research contained pyrite and marcasite - minerals which after oxidation cause acidification in soils $[7,10]$. The use of lime for reclamation purposes in a dose of $50 \mathrm{Mg} \mathrm{ha}^{-1}$ as a neutraliser caused significant changes in the soil $\mathrm{pH}$ value during the initial years. In certain plots $\mathrm{pH}$ in terms of $\mathrm{H}_{2} \mathrm{O}$ reached the values 7,8 [8]. With time $\mathrm{pH}$ values decreased and reached the level found during this research. It may be supposed that in the following years values will further decrease. The reason for this is the leaching of lime from soil masses by water and the acidifying influence of the above mentioned minerals containing sulphur.

After 24 years of reclamation, the content of organic carbon was within the range of 436.9 to $1.5 \mathrm{~g} \mathrm{~kg}^{-1}$. The content of organic carbon in the analysed samples decreased as the sampling depth increased. The highest content of organic carbon was found at the level $\mathrm{O}$ of forest litter. The sources of this component in the formations under research were dust admixtures, large lignite chips and dead parts of plants growing in the area of the dump [8]. The relationship similar to changes in organic $\mathrm{C}$ was found in the case of total nitrogen (Table 3). A very important relationship was found between the content of total nitrogen and the content of organic $\mathrm{C}-\mathrm{r}^{2}=0.93$ (Fig.1).

An important factor determining a number of processes occurring in soils is the C:N ratio. The lower it is the higher biological activity in soil. In the formation under research values of this ratio varied and fluctuated within the range of 1.5-13.0 (Table 3).

During the formation of soil structure the main part is played by humic compounds. The humification process consists of a (decomposition or synthe- 
sis) reaction during the formation of humic substances [3]. Humic substances (HS) constitute the main part of carbon compounds. UV radiation causes partial degradation of Hs particles, which changes their structure and speeds up their mineralization. Humic substances may modify physiological processes occurring in higher plants. Metabolic changes in organic matter are very complicated and they are strongest in the surface layer of soil, the so called topsoil. Microorganisms and microfauna are responsible for those processes $[1,5]$. The time needed for organic compounds to change into organic matter - humus - depends among other factors on climatic conditions [5].

TABLE 3. BASIC PHYSICAL AND CHEMICAL PROPERTIES OF POST-MINING FORMATIONS

\begin{tabular}{|c|c|c|c|c|c|c|c|}
\hline \multirow{2}{*}{ Plot } & \multirow{2}{*}{$\begin{array}{c}\text { Depth } \\
(\mathrm{cm})\end{array}$} & \multicolumn{2}{|c|}{$\mathrm{pH}$} & TOC & $\mathrm{N}_{\mathrm{t}}$ & \multirow{2}{*}{ TOC: $\mathrm{N}_{\mathrm{t}}$} & \multirow{2}{*}{$\mathrm{C}_{\mathrm{kh}}: \mathrm{C}_{\mathrm{kf}}$} \\
\hline & & $\mathrm{H}_{2} \mathrm{O}$ & $\mathrm{KCl} 1 \mathrm{M}$ & \multicolumn{2}{|c|}{$\left(\mathrm{g} \mathrm{kg}^{-1}\right)$} & & \\
\hline \multirow{4}{*}{1} & $0-3$ & 5.0 & 4.3 & 423.5 & 12.3 & 34.43 & 1.5 \\
\hline & $3-8$ & 5.3 & 4.8 & 6.0 & 3.5 & 1.71 & 1.5 \\
\hline & $8-30$ & 4.1 & 3.4 & 1.7 & 0.7 & 2.43 & 3.4 \\
\hline & $30-60$ & 3.8 & 3.3 & 1.5 & 0.5 & 3.00 & 4.4 \\
\hline \multirow{4}{*}{2} & $0-1,5$ & 3.9 & 3.3 & 387.3 & 11.7 & 33.10 & 2.8 \\
\hline & $1.5-12$ & 5.8 & 5.4 & 18.9 & 0.5 & 37.80 & 9.3 \\
\hline & $12-30$ & 3.5 & 3.1 & 21.2 & 0.7 & 30.28 & 13.0 \\
\hline & $30-60$ & 3.2 & 2.7 & 19.4 & 0.7 & 27.71 & 8.6 \\
\hline \multirow{4}{*}{3} & $0-2.5$ & 4.1 & 3.5 & 319.0 & 11.2 & 28.48 & 2.3 \\
\hline & $2,5-9$ & 3.9 & 3.3 & 17.2 & 0.5 & 34.40 & 6.7 \\
\hline & $9-30$ & 3.6 & 3.2 & 13.5 & 0.3 & 45.00 & 6.3 \\
\hline & $30-60$ & 3.0 & 3.0 & 39.0 & 1.1 & 35.54 & 12.0 \\
\hline \multirow{5}{*}{4} & $0-3$ & 4.2 & 3.4 & 436.9 & 12.9 & 33.89 & 2.7 \\
\hline & $3-7$ & 4.5 & 4.0 & 14.5 & 0.7 & 20.71 & 3.4 \\
\hline & $7-22$ & 4.4 & 4.0 & 10.3 & 0.5 & 20.60 & 5.9 \\
\hline & $22-42$ & 3.7 & 4.4 & 14.7 & 0.3 & 49.00 & 6.5 \\
\hline & $42-60$ & 3.4 & 3.0 & 11.9 & 0.3 & 39.66 & 4.0 \\
\hline \multirow{5}{*}{5} & $0-3$ & 6.3 & 5.8 & 42.2 & 3.9 & 10.82 & 1.8 \\
\hline & $3-7$ & 4.9 & 4.2 & 10.4 & 2.1 & 4.95 & 2.4 \\
\hline & $7-23$ & 3.9 & 3.4 & 16.8 & 1.7 & 9.88 & 4.3 \\
\hline & $23-32$ & 3.9 & 3.5 & 6.7 & 1.5 & 4.47 & 4.0 \\
\hline & $32-60$ & 3.7 & 3.2 & 3.9 & 1.0 & 3.90 & 2.9 \\
\hline \multirow{4}{*}{6} & $0-3$ & 4.9 & 4.1 & 103.4 & 6.4 & 16.16 & 3.3 \\
\hline & $3.0-10$ & 4.7 & 3.1 & 4.9 & 2.1 & 2.33 & 3.1 \\
\hline & $10-32$ & 3.9 & 3.2 & 5.0 & 2.1 & 2.38 & 5.2 \\
\hline & $32-60$ & 3.7 & 3.1 & 2.0 & 1.9 & 1.05 & 4.4 \\
\hline
\end{tabular}

During the long-term experiment carried out in the area of the former lignite mine near Lęknica it was found that the $\mathrm{C}_{\mathrm{kh}}: \mathrm{C}_{\mathrm{kf}}$ ratio characterising the level of decomposition of organic matter considerably exceeded the value 1.0 and increased as the sampling depth increased (Table 3). In the profiles under 
research the extracted compounds indicated significant domination of humic acids. A similar fractional composition was found in the dumps of the coal mine "Turów" where the fraction of humic acid dominated significantly. The results described correspond to the results of the research on the soil of post-mining dumps „Bełchatów” and „Piaseczno” in the more fertile variants $\left(\mathrm{C}_{\mathrm{kh}}: \mathrm{C}_{\mathrm{kf}} 1.38\right.$ and 1.70 respectively) and in the dump ,Smolnica" in the variant without fertilisation [12].

During this research slow mineralization was found, i.e. accumulation of organic mass in each of the profiles under research. The lowest ratios of the marked organic acids were found in the samples taken from the control plot where they fluctuated within the range of 1.5 to 4.4. The samples taken from plots 2,3,4,5,6 had very similar values of the ratios between humic acids and fulvic acids.
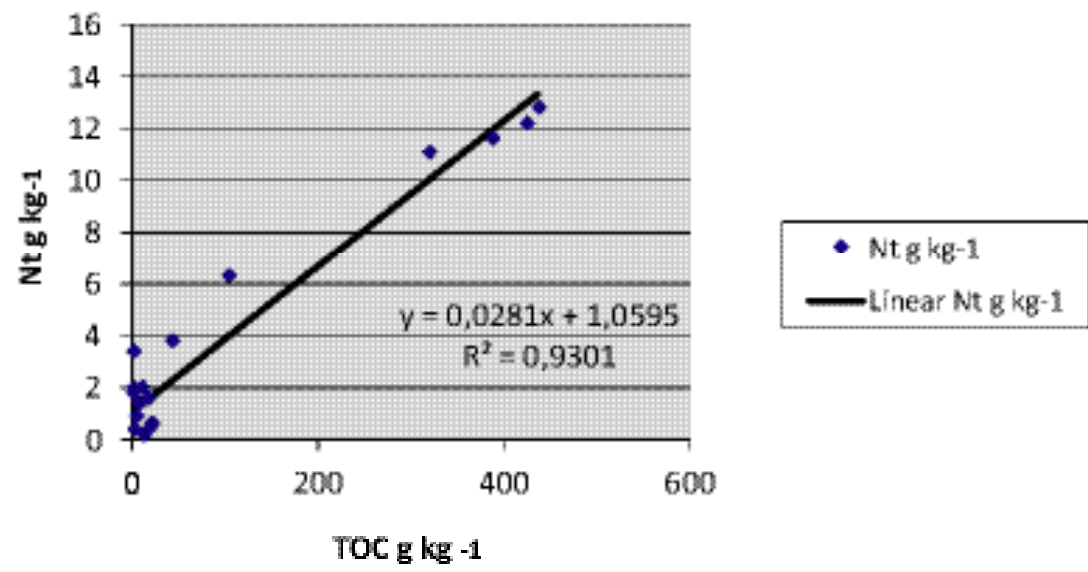

Fig.1. Dependence between the content of total nitrogen and the content of organic carbon in the soils studied.

\section{CONCLUSIONS}

The results of this research lead to the following conclusions:

1. The sorption capacity of the soil in the surface layers of the profiles under research was considerably higher than in deeper layers.

2. The post-mining formations under research were strongly acidified. The $\mathrm{pH}$ value decreased as the sampling depth increased.

3 . The contents of total organic carbon and total nitrogen in surface layers of soils were considerably higher than in deeper layers of the profiles.

4. The ratio between total organic carbon and total nitrogen was highest on the surface levels of all profiles under research. This ratio usually decreased as the sampling depth increased. 
5. The ratio between humic acid carbon and fulvic acid carbon $\left(\mathrm{C}_{\mathrm{kh}}: \mathrm{C}_{\mathrm{kf}}\right)$ was greater than 1.0 and increased as the depth increased, which means that the organic mass in the formation under research is strongly humified.

6. It was found that mineral fertilisation variants used in the experiment over the period of 20 years had not had a significant influence on the characteristics under research.

\section{REFERENCES}

[1] B a d u r a L.: Zesz. Nauk. AGH, Kraków, 2/9, 147, 2004.

[2] D zi a d o w i e c H., G o n e t S.: Przewodnik metodyczny do badań materii organicznej gleb. Prace Komisji Naukowych Polskiego Towarzystwa Gleboznawczego, Warszawa, 120, 1999.

[3] F a s u ro vá N., P o s p íš il ová L.: Humic Substances Ecosystems, 8, 42, 2009.

[4] Frouz J., K a lč i k J.: E k o 1 ŏ g i a, Bratislava, 25/4, 388, 2006.

[5] G o n e t S, M arki e w i c z M.: Rola materii organicznej w środowisku. Polskie Towarzystwo Substancji Humusowych, Wrocław, 2007.

[6] G o n e t S.: Metody badań substancji humusowych ekosystemów wodnych i lądowych. AR Szczecin, 7, 2004.

[7] Gr e i n e rt H.: Zesz. Nauk. Uniwersytetu Zielonogórskiego, 84, 4, 1988.

[8] Gre in er t H., D rab M., Gre in ert A.: Studia nad efektywnością zwałowisk fitotoksycznie kwaśnych piasków mioceńskich po byłej kopalni węgla brunatnego w Łęknicy. Uniwersytet Zielonogórski, 2009.

[9] Krzaklewski W., Wójcik J: Doskonalenie technologii rekultywacji biologicznej zboczy i kształtowanie biotopu dla leśnego zagospodarowania zwałowiska zewnętrznego KWB „Turów”. IKiOS AGH, Kraków, 12, 2007.

[10] Krzaklewski W., Kowalik S., Wójcik J.: Rekultywacja utworów toksycznie kwaśnych w górnictwie węgla brunatnego. AGH, Kraków, 1997.

[11] Mocek A., Drzy mała S., Mas zne r P.: Geneza, analiza i klasyfikacja gleb. Wyd. AR Poznań, 1997.

[12] P i etrzy k ow s k i M.: SYLWAN, 154 /11,742, 2010.

\section{ZMIANY ZAWARTOŚCI SUBSTANCJI HUMUSOWYCH, ODCZYNU ORAZ WŁAŚCIWOŚCI SORPCYJNYCH W REKULTYWOWANYCH GRUNTCH POWSTAŁYCH NA TERENACH POKOPALNIANYCH}

Praca zawiera wybrane wyniki analiz właściwości gruntów pokopalnianych byłej kopalni węgla brunatnego" Przyjaźń Narodów” w rejonie Łęknicy- województwo lubuskie. Powstałe grunty posiadały bardzo niekorzystne właściwości: skład granulometryczny (piasek gliniasty lekki) sprzyjał erozji wodnej, odczyn utworów był silnie kwaśny, zawartości węgla organicznego i azotu ogółem były silnie zróżnicowane i najwyższe w poziomach powierzchniowych profili. Stosunki $\mathrm{C}_{\mathrm{kh}}: \mathrm{C}_{\mathrm{kf}}$ zwiększały się wraz ze wzrostem głębokości poboru próbek. 